\title{
A Shift from the Selling-Goods to the Selling-Experiences in a Production Goods Company:
} New Challenges for Daikin Technology

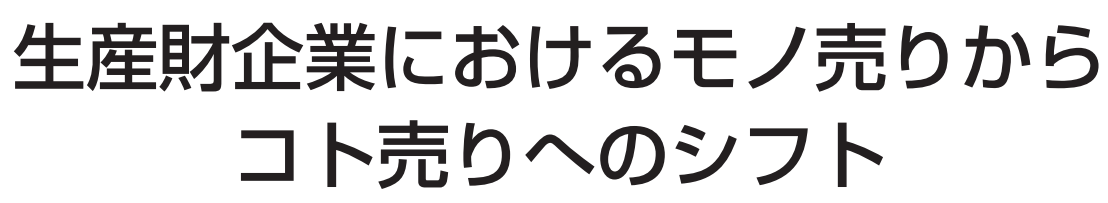

一 技術のダイキンによる新たな挑戦

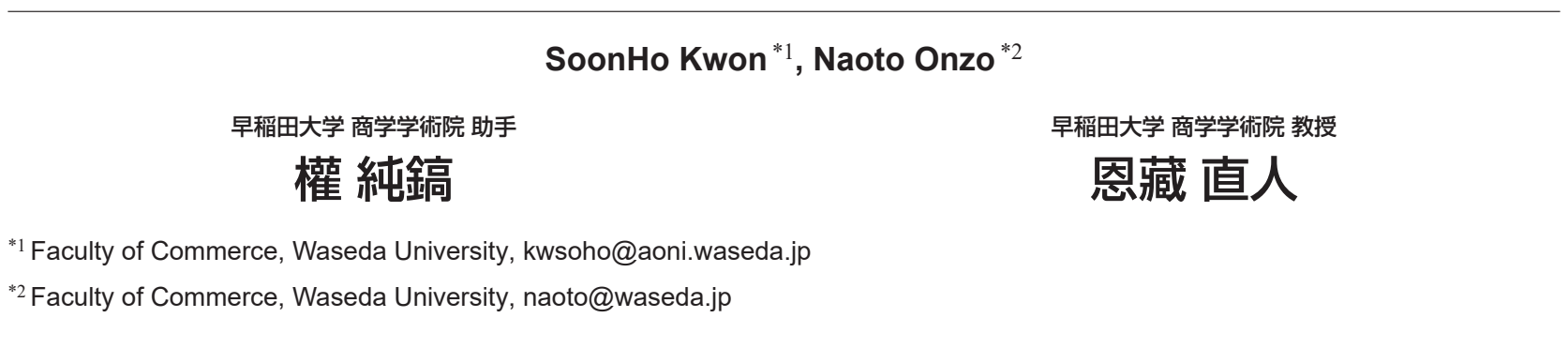

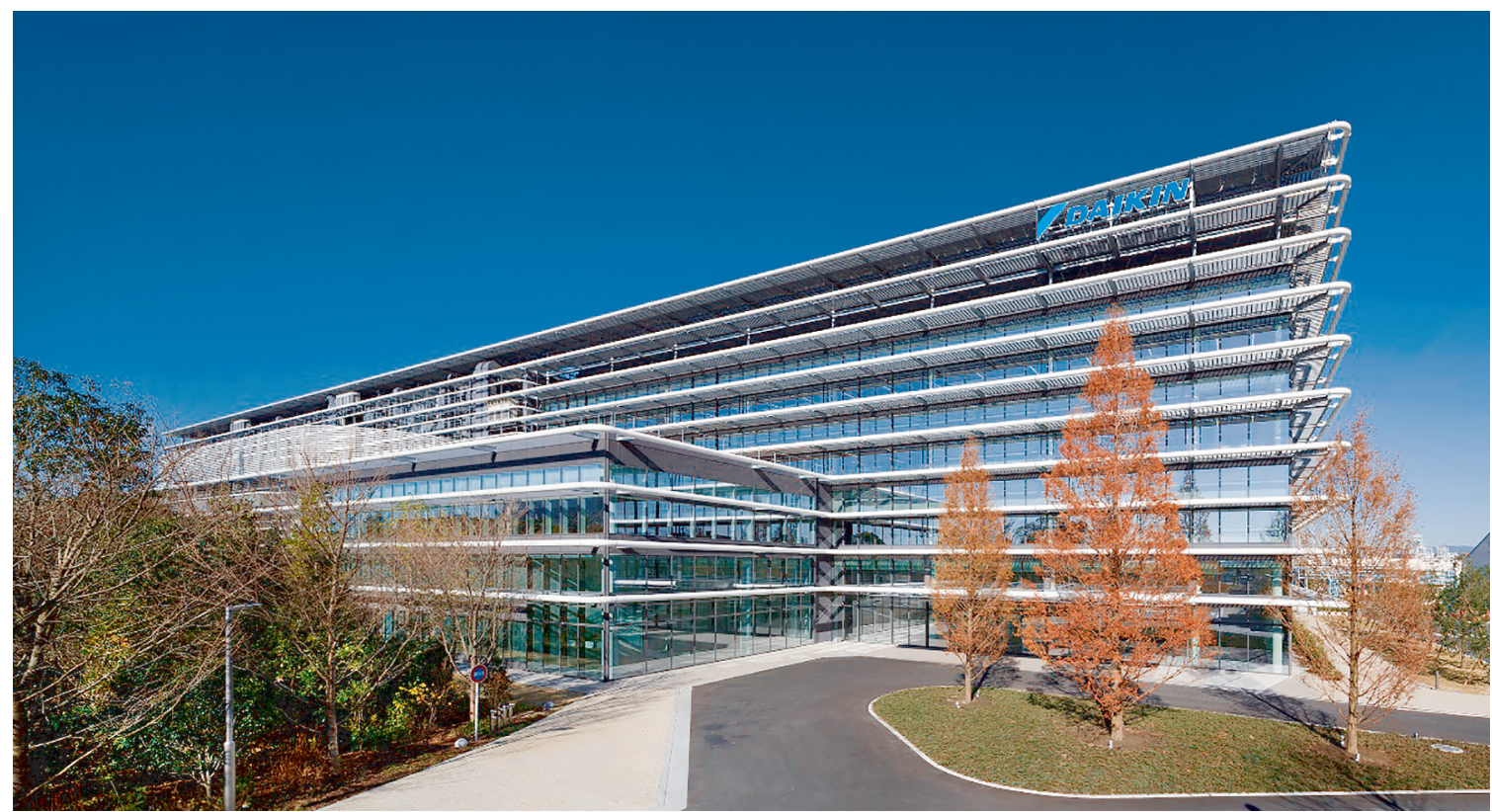

(出典) Daikin Industries, Ltd.（2019b）ょり引用

Abstract : The outstanding ability of the Daikin Industries Ltd. to develop new products has helped it to overcome successive crises. The company recently set out to shift from a product-oriented to a customer-oriented approach, and it has derived substantial benefits from the change. One example is what the company calls AaaS - the Air-conditioning facility subscription service. This involves the constant supply of fresh air, ranging from the installation of an airconditioning facility to the provision of operational plans, maintenance or after-sales service for a monthly fee. The company, as part of its focus on potential consumer needs, redirects its attention from the traditional "selling-materials 
policy" to a "selling-experience policy". The aim of AaaS is not just to benefit users by optimizing air-conditioning, but also to save them money. With the heightened commoditization in recent years, it has become challenging for companies to sustain their competitive advantage simply through the quality or functionality of their products. The AaaS case of the Daikin suggests that companies can provide users with new values without changing the lineup of products by shifting from product-oriented to customer-oriented service.

Keyword : Subscription, Customer orientation, Service marketing

要約 : ダイキン工業株式会社は 90 年以上を超える歴史の中で, 優れた製品開発によって成長を遂げてきた。近年, 同社は製品 志向から顧客志向への転換を試み始め, 空調設備のサブスクリプション・サービス「AaaS (エアアズアサービス)」で成果をあ げつつある。AaaS は空調設備ではなく空気を提供するという発想であり, 月額料金で空調設備の設置工事から最適な運用の提 案, メインテナンス, アフターサービスに至るまで, 快適な空気を安定的に供給するための一連のサービスである。顧客自身も 気づかない潜在的な二ーズに注目したダイキンは, 既存のモノ売り発想では対応が困難であった課題をコト売り発想への転換に よって解決を試みた。同サービスは空調の最適化を実現することでランニングコストを削減するなど, コストの面においても顧 客にメリットをもたらしている。昨今のコモディティ化の深化に伴い, 製品の機能や品質だけで競争優位性を保つことが困難に なってきている中，ダイキン工業の AaaS 事例は，製品志向から顧客志向に組織の軸足を移すことで，提供製品を変えることな く新しい価值を提供できることを示唆している。

キーワード : サブスクリプション, 顧客志向, サービス·マーケティング

\section{I.はじめに}

ダイキン工業株式会社（以下，ダイキン工業）は，モ ノづくりの企業として 90 年以上の歴史を誇る。1924 年 の創業当時は, 飛行機部品のラジエーターチューブやワー プタイングマシン（織機の経糸をつなぐ装置）などを生 産していた。戦後は, 現在の主力事業である商業用・業 務用空調事業に参入し, 1951 年に日本初のパッケージ型 エアコンディショナーの開発によって本格的な事業展開 が始まった。その後, 同社の空調事業は 1982 年に大き な転換期を迎えた。同年度に開発したビル用マルチ方式 の空調システムにより世界に乗り出し, 日本を代表する グローバル企業として飛躍し始めたからである。

また，住宅用空調設備においても模倣困難な製品を打 ち出している。同社は 1999 年に世界初の無給水加湿式 ルームエアコンの「うるるとさらら」という革新的な製 品を発売し, その 4 年後の 2003 年には家庭用ルームエ アコンで通年のシェア第 1 位を獲得する。

このように，製品志向で成長してきた企業が，モノ売 りではなくコト売りへの転換を試み始めた。その大きな 一歩が今回注目した AaaS（Air as a Service）である。本
稿では，同社が AaaS に乗り出すにあたっての思い，お よびエクセレンスとしての当該ビジネスの本質に光を当 ててみた。

\section{II. ダイキン工業の沿革と事業概要}

\section{1. 沿革 1$)$}

ダイキン工業の歴史は，創業者である山田晁氏によっ て 1924 年に設立された合資会社大阪金属工業所に始ま る。設立当時の事業内容は, 飛行機部品（放熱管および 同用管の製作販売)，一般金属の圧搾および搾伸作業など が中心となっていた。1930 年以降からは海軍・陸軍双方 から軍指定工場とされ, 高抗張力・高耐圧力を要する金 属部品, 航空機用部品, 薬萊などを納品していた。

当時, 海軍 - 陸軍両方からの指定工場は大企業（日立 製作所や三菱航空機など） 30 社ほどであったが，その中 で合資会社形態は大阪金属工業所のみであり, その後も 実力を認められて順調に成長を続けた。1934 年には大阪 金属工業株式会社の創立総会が開催され, 山田昆氏が代 表取締役社長に就任するなど，今日のダイキン工業の原 型が作られた。 
Marketing Case マーケティングケースー シリーズ 139

現在のダイキン工業の主力事業である空調事業に本格 的に乗り出したのは，1951 年に発売した日本初のパッ ケージ型エアコンがきっかけである。パッケージ型エア コンの発売後, 日本電信電話局（現, NTT) や銀行, 飲 食店や娛楽施設などへの販売活動が実を結び，そこでの 実績をもとに船舶の空調設備, 住宅用空調設備など空調 事業の多角化を行うことになる。

さらに, 1960 年代初頭には空調事業の海外業務開始に 向けて，アジア・オセアニア地域への進出の足がかりを 整え始め，1966 年には海外業務が本格的に開始される。 また，1963 年には社名変更という大きな出来事があっ た。創業 40 周年を迎えた大阪金属工業株式会社は，創 業者の山田晁社長の決断により，社名を「大阪金属工業 株式会社」から「ダイキン工業株式会社」に変更したの である。

1970 年代には石油危機や大冷夏に見舞われるなど厳し い状況に直面するものの, パッケージエアコンで初めて の “フロンヒート”を搭載した暖房機能, 薄さ 32 セン チの床置型エアコン, さらに 1982 年には現在にもつな がる「ビル用マルチエアコン」が発売されるなど，画期 的な新製品開発によって危機を乗り越えてきた。

バブル経済の崩壊による経済的な影響が広がっていた 1994 年に 2 代目社長の山田稔氏が会長に退き, 井上礼之 専務の代表取締役社長就任が発表された。新しく社長に 就任した井上社長のもとで，ダイキン工業はさらなるグ ローバル化を推し進めてきた。

とりわけ，グローバル化の推進力となったのは, 1982 年に発売されていた「ビル用マルチ方式」による空調で あったと言われている 2)。この空調設備は既存の方式に 取って代わり，国内はもちろん，海外の多くの企業が取 り入れるようになった。また, 1960 年代から 70 年代に かけて積極的に海外進出の基盤を築いてきたことも相 まって, 90 年代以降, 同社のグローバル化は順調に成長 しており，2018 年度には売上全体（空調事業，化学事 業，その他）の $76 \%$ が海外となっている。

今日では, 欧州, インド, 中国, アジア，アメリカ， 日本の 6 拠点で現地のニーズに応える製品を開発し，世 界に 100 を超える工場で現地生産, 150 力国以上で事業 展開をしており，従業員の外国人比率が 8 割を超えるな
ど，名実ともに日本を代表するグローバル企業として位 置づけられている。

\section{2. 事業概要 3)}

ダイキン工業の事業は空調事業が $89.6 \%$, 化学事業が $8.1 \%$ ，その他が $2.3 \%$ を占めている (2018 年度基準) ${ }^{4)}$ 。 空調事業は住宅用，商業用・業務用，アフターサービス 等の事業からなり, 化学事業としては冷媒や半導体用途, 自動車用途の事業, その他事業としては油圧機器, 酸素 濃縮器などを展開している。

全体の事業の中でも空調事業の占める割合が高いが, 空調事業の高い競争優位性には店舗・オフィスエアコン の「スカイエア」シリーズや，ビル用マルチエアコンな ど革新的な製品を生み出し続けてきたこと, また他社か らの追随が困難なコア技術を保有していること（インバー ター, ヒートポンプ, 冷媒制御）が背景にあると考えら れる5)。

1970 年代以降, 商業用・業務用を中心としていた空調 事業は，その領域を住宅用空調設備までに広げており， 現在は国内空調メーカーの 3 強の一角を占めている。ま た，国内のみならず，海外における空調事業成長率も伸 べており, 2018 年度における空調事業の売上高は 22,222 （億円）で，そのうち日本での売上高は 4,817（億円）， 欧州は同 3,322（億円）, 中国は同 3,422（億円）, アジ ア・オセアニアは同 3,584（億円）, アメリカは同 6,456 (億円), その他地域は同 621（億円）となり, 空調事業 の約 $78 \%$ が海外事業による売り上げであることがわか る。営業利益も順調に推移しており, 同社は 2010 年以 降, 増収増益を続け, 7 期連続での最高営業利益を目指 している。

\section{（1）商業用・業務用空調事業}

現在，ダイキン工業の事業全体の 9 割弱を占めている 空調事業は, 石油危機などの外部環境の影響によって危 機に直面したこともあるが，1978 年に店舗用エアコンの 「スカイエア」シリーズをきっかけに事業を立て直した。 「スカイエア」シリーズの天吊型室内機は $19.8 \mathrm{~cm}$ という 当時としては驚きの薄さを実現し，ヒット商品となった。 このシリーズ以降, 店舗型エアコンの主流は床置型から 


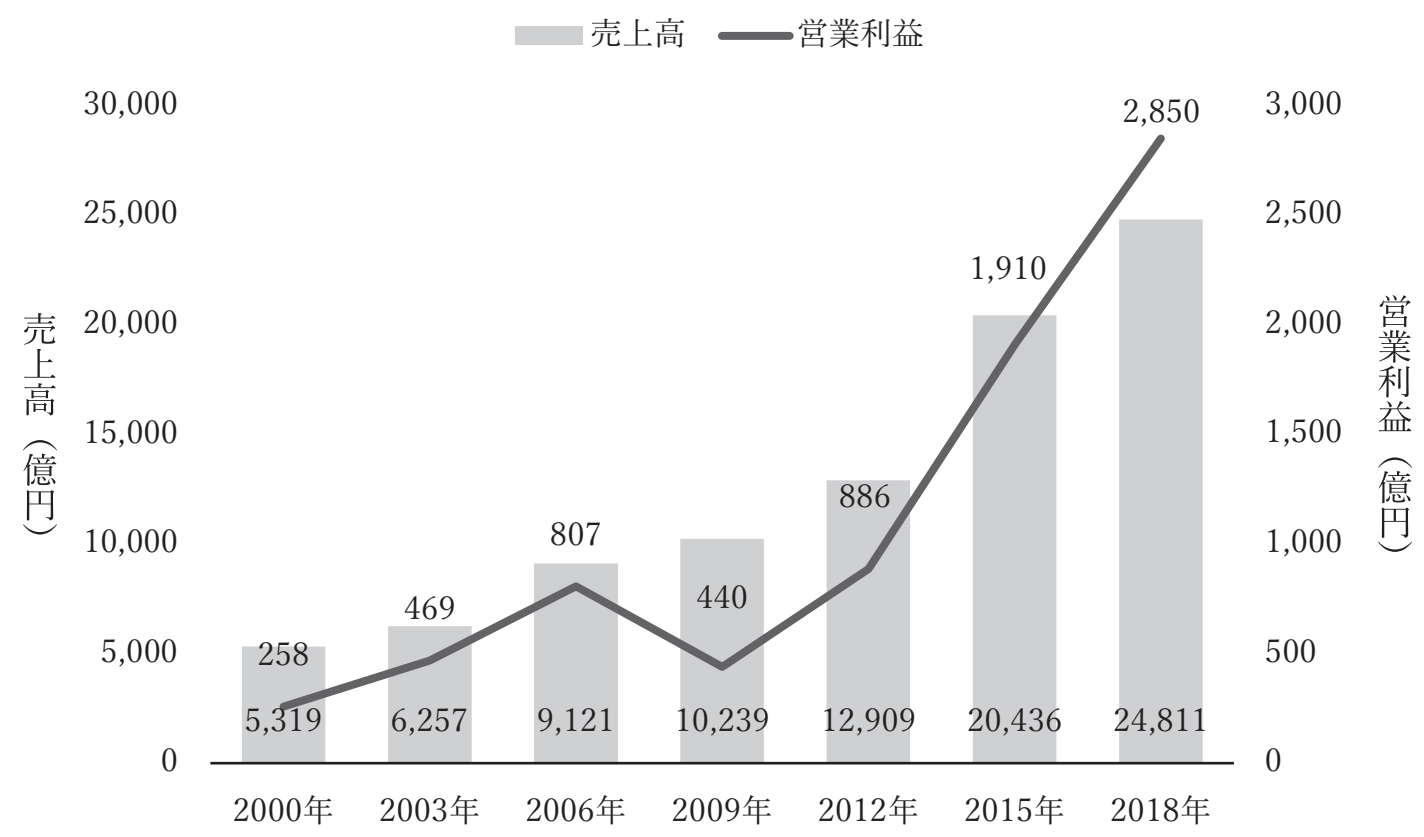

(出典) Daikin Industries, Ltd. (1996, 2001, 2006, 2011, 2016, 2019a）をもとに作成

天吊型へ転換し, さらにはデザイン性を求めて現在でも 多く見られる天井埋め込みカセット形へと進化して いった。

この「スカイエア」シリーズが軌道に乗り始めると, 7〜8 階建ての中小ビル市場をターゲットとした「ビル用 マルチ方式」の空調設備の開発に着手し, 1982 年に商品 化した。この方式の導入によって，これまでの熱源機器 を一力所に集中設置して中央管理室などから一括で空調 を制御するセントラル方式あるいはダクト方式と呼ばれ ている空調設備に取って代わり, 部屋ごとあるいはフロ アごとに空調を制御できるようになった。

そのことによって, 省エネルギーが実現し， ランニン グコストは従来と比べて $20 〜 40 \%$ 安く抑えられた。室内 機の小型化も進み, 省スペースで設置施工も容易である ことから, 中小ビルの空調はダイキン工業のマルチ方式 が主流となり，大きな成功を収めた。また，ビル用マル チエアコンは国内だけなく, 海外進出の際にも重要な役 割を果たす。当時, アメリカではセントラル方式の空調 設備が主流であったが，セントラル方式は建物の設計段
階からダクトやパイプの配管の必要があり, 熟練した専 門家がいないと設置が難しいと言われていた。しかし， マルチ方式はカタログだけで設置できるという利点を有 し, 既存の方式よりも設置が簡単であり, 熟練度の低い セミプロでも設計ができるため, 海外でも広く受け入れ られるようになった ${ }^{6)}$ 。現在でも, 商業用・業務用空調 事業はダイキン工業の主力事業として位置づけられる。

\section{（2）住宅用空調事業}

1972 年度までにダイキン工業は産業用空調部門を中心 とした事業を展開しており, 全社総売上高の 7 割を超え るまでに至っていた。同時期に, 住宅用空調専門の滋賀 工場の稼働がスタートしたことを皮切りに住宅用空調事 業への本格的な参入を果たしたものの, 最初は販売台数 に見合った利益が得られなかった。しかし, その後は順 調に販売台数が伸び, 1975 年のわずかな売り上げ減を除 けば，一貫して売上高が増加していった。

その後, 1980 年代に入ってからダイキン工業はイン バーターエアコンの開発を検討するものの, コスト面か 
Marketing Case マーケティングケースーシリーズ 139

ら採算が取れないと判断し，同社の特許技術“フロンヒー ト”をもに, 冷暖房可能なヒートポンプタイプへ移行し た。しかし，その翌年の 81 年には競合他社からインバー ターエアコンが発売され，1983 年には家電メーカーが 次々とインバーター機を発売したことでインバーターの 価格が低下した。そこで, 同社も 1984 年になってイン バーター搭載機種の住宅用エアコンの発売に乗り出した。

インバーターエアコンで遅れをとっていたダイキン工 業は, 1994 年には住宅用空調の社内生産の存続を議論す るほどの赤字に陥っていた。この赤字から脱却し，2003 年に国内シェアトップを実現するまでには，独自のハイ サイクル生産方式と「うるるとさらら」シリーズのヒッ トが背景にあった。

この新しい生産方式は, 生産機種と生産台数を出荷連 動で柔軟に変化させるダイキン工業独自のものであり, 市場の変化に対応した適切な商品を適切な時期に供給で きる体制を可能にしている。この独自の生産方式によっ て，2002 年には日本設備管理学会が選定した「第一回も のづくり大賞」を受賞し，さらに，2004 年には「第一回 日経ものづくり大賞」の「日経 BP 特別賞」を受賞した。 これらの受賞は, ハイサイクル生産方式でリードタイム
を半減するなど，住宅用エアコンでシェアトップに躍り 出る原動力となった生産革新が, 高く評価されたことを 物語っている。

さらに，生産方式だけでなく，イノベーティブな製品 も同時期に開発された。1999 年から販売を始めた「うる るとさらら」は, 世界初の外気から水分を取り込む新加 湿方式 (うるる加湿) と室温を下げずに除湿が可能な再 熱除湿方式 (さらら除湿) を搭載したルームエアコンで あり，ダイキン工業の技術の結晶であると言われている。 発売から 20 年以上経つ「うるるとさらら」は, 現在も なおダイキン工業の主力商品である。

\section{（3）グローバル戦略 7)}

現在, ダイキン工業の空調事業の海外売上比率は 78\% にも上り, 世界 28 力国 85 力所以上に生産拠点を有して いる。同社の空調事業のグローバル化の始まりは, 1960 年代までに遡る。1966 年の 9 月，イギリス人の R.Cヒッ グスから地中海のマルタ国への代理店設置の提案があっ たことをきっかけに, 当時のマルタ国では空調設備に関 する需要が急速に伸びていたこと, またヨーロッパや北 アフリカへの輸出拠点の可能性を考え, 同年の 10 月に

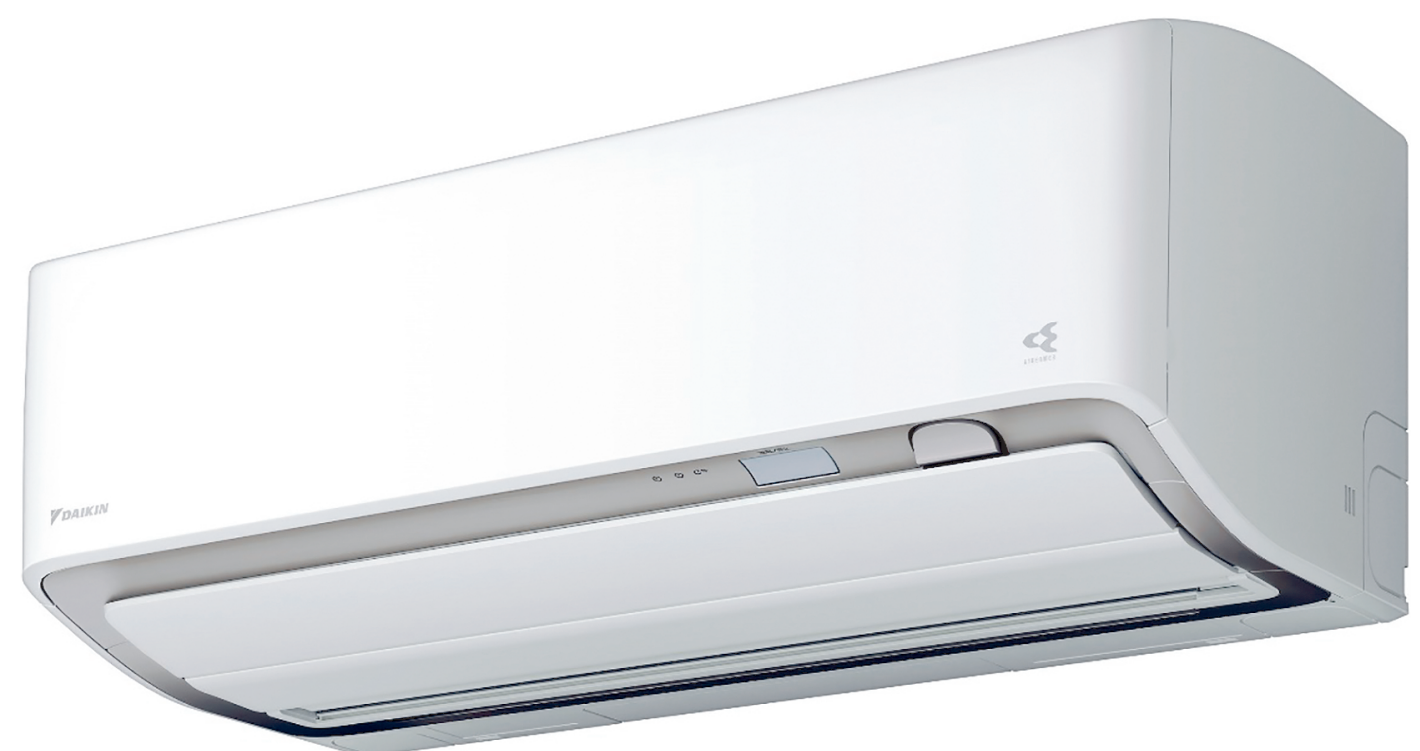

（出典） Daikin Industries, Ltd.（2019b）から引用 
はダイキンエアコンディショニング社（DAC）が設立さ れた。その後も，順調に売上高が伸びていき，1970 年に はヨーロッパ全域に DAC 社傘下の代理店が 15 社まで増 えていった。

同時期に，東南アジア・オセアニア市場にも空調機の 輸出が拡大していた。しかし, 代理店が増えるにつれて, いくつかの課題も浮き彫りになってきた。その一つが, 設置工事やアフターサービス，空調の専門技術者の不足 である。そのため, 70 年代には代理店を設置するだけで なく，積極的な資本参加による経営権の獲得と人材育成 プログラム, 完成品の輸出から現地でのノックダウン生 産が開始された。

しかし，グローバル進出は常に順調だったわけではな い。ヨーロッパでは 2 度の石油危機で売上高が激減した ことや労働組合のストライキに見舞われるなど，様々な 難題に直面していた。また，アメリカ進出の際には，世 界的な競合他社の存在とすでに空調に関する需要が確立 していたため, 高い参入障壁があった。

このような課題に直面した 1985 年には, 国や地域ご とに業績のばらつきが出てきたことを踏まえ，すべての 地域に同程度の経営資源を投下寸るのではなく, 商品別・ 国別で資源の投入量を変えていく重点主義へ転換するこ とで，グローバル戦略の再編成を試みたのである。

さらに, 1998 年にはグローバル戦略本部が設置され, 従来のグローバル戦略を見直し，国際化に対応できる組 織体制が整えられた。同年以降，早い時期から進出して すでに現地生産まで行っているヨーロッパでの販売網の 充実，また，競合他社より進出が遅かった中国への本格 的な進出が始まる。

2005 年には, 空調部門での売上第 2 位のトレーン社と 並び，第 1 位のキャリア社を追随するところまでシェア を伸ばしていた。同社がグローバルシェア第 1 位を実現 するために取り組んだことの一つに，2007 年にマレーシ ア企業の OYL インダストリーズ社（以下，OYL 社）を 買収したことが重要なポイントとなる。

OYL 社は，マレーシアに本社を置き，総合空調事業を 全世界で展開しているグローバル企業である。買収後は, 事業の規模や企業組織を飛躍的に拡大していき，空調・ 冷凍機器部門の 2005 年度における売上が 6,416 億円だっ
たところ, 2 年後の 2007 年度には売上が 1 兆 1,319 億円 となり，急速な成長を成し遂げたのである。

その後, リーマンショックの影響で世界経済不沉から 減収減益となったが, 社内で重点課題とされていた海外 工場建設が次々と進行し，また中国での業務提携など, 不況の影響への対策が着々と進められていった。このよ うな取り組みが実り，2010 年では空調事業部門で世界の シェア第 1 位を達成した。

(4) テクノロジー・イノベーションセンター8)

ダイキン工業のグローバル戦略は, リーマンショック の影響はあったものの, その後に V 字回復しながら順調 に業績を伸ばしてきた。しかし，環境問題への規制強化， 新興国市場の開拓, 高付加価值のソリューション・ビジ ネス事業の台頭など，激化していくグローバル競争を勝 ち抜くためには今まで以上に新たなイノベーションを起 こしていかなければならないという判断のもとで, 2015 年に淀川製作所敷地の中にテクノロジー・イノベーショ ンセンター（以下，TIC）を設立した。

現在，TIC はダイキン工業の技術開発の世界的拠点に なっている。日本にある TIC で世界のベースモデルを開 発し, このベースモデルをもとに海外ではカスタマイズ 開発を行っている。同施設では空調技術であるインバー ター技術やヒートポンプ技術, 冷媒制御技術の研究を行っ ているが，これらの技術は模做が難しく，ダイキン工業 のコア技術と言われている。

研究 - 開発については, 社内外の様々な分野の技術者 同士で交流を促す仕組み作り, 東京大学, 大阪大学, 奈 良先端科学技術大学院大学, 京都大学等との産学連携を 進めるなど，オープン・イノベーションの促進に向けて の取り組みが行われている。また，異業種他社との協創 も行っており，世界中の異分野の研究者同士による交流 を進めている。

同施設においては様々な取り組みが行われているが, その一つとして, 2013 年にグランフロント大阪のナレッ ジキャピタル内に開設したショールーム「フー八大阪」 と連動した顧客協創型イノベーションによる新商品開発 がある。TICに押いてこれからの商品やサービスに関す る仮説を構築し「「フー八大阪」で検証するという。 
Marketing Case マーケティングケース — シリーズ 139

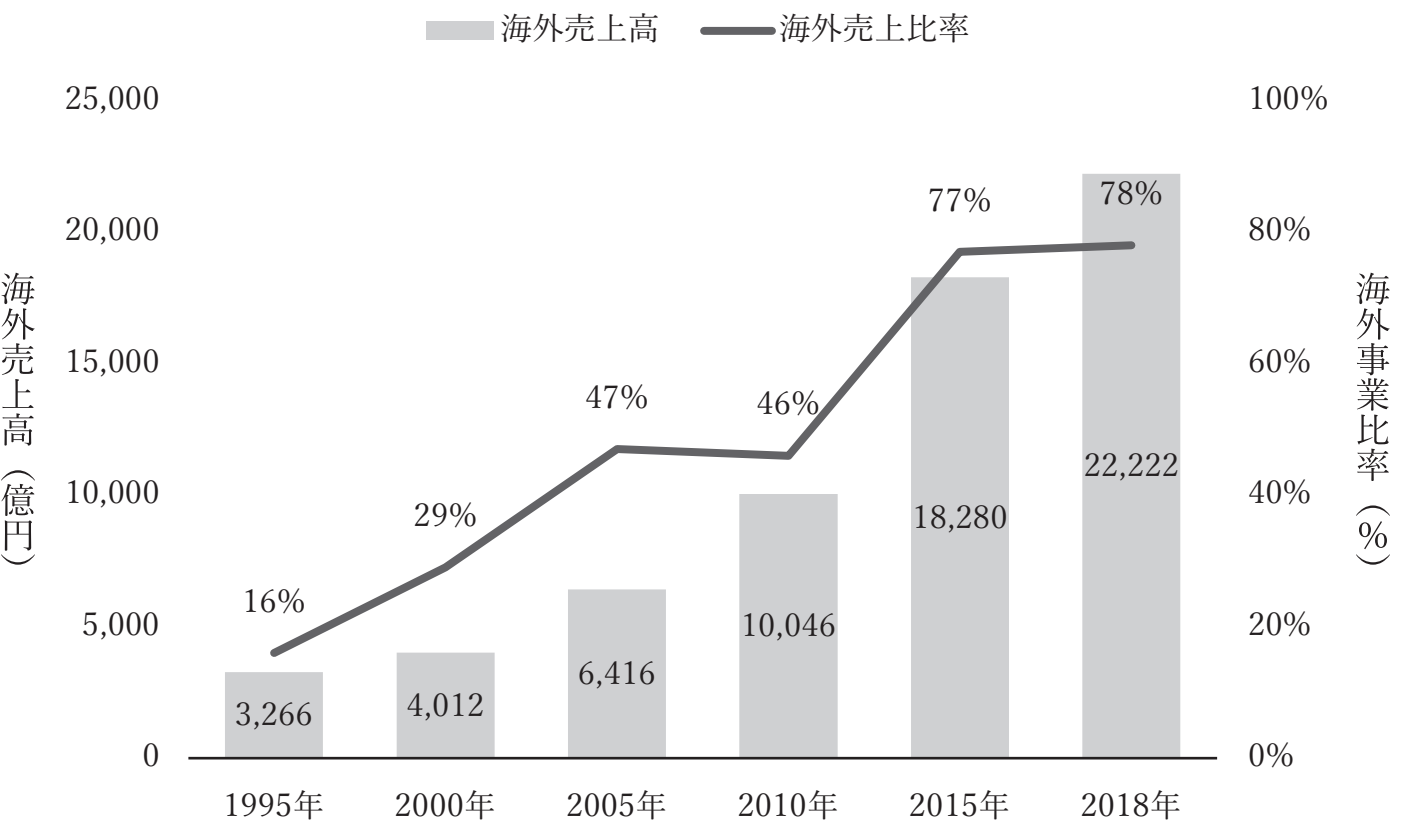

（出典）Daikin Industries, Ltd.（1996, 2001, 2006, 2011, 2016, 2019a）をもとに作成

また，需要が高まっている AI 人材に注目しており， 2017 年には AI 分野の技術開発や事業開発を担う人材を 育成する社内講座「ダイキン情報技術大学」を開講した。 開講された授業には，理系出身の新入社員からの希望者 100 人が受講し，入社から 2 年間はこの企業大学で学ぶ ことに専念するという。

\section{III. 新しいビジネスモデル「サブスクリプション」 の導入}

\section{1. 事業背景}

このように，ダイキン工業は順調に成長し，売上高を 伸ばしてきた。しかし，ダイキン工業の専任役員でテク ノロジー・イノベーションセンター技師長の小林氏の脳 裏には, 将来的には空調設備の販売だけではなく,「快適 な環境を提供するビジネス」や「製品ではなく，空気を 提供するという発想」が求められるという思いがあった。 さらに先を見据えて，空調事業をモノ売りではなく、コ
ト売りとしての可能性を検討しながら, いくつかのビジ ネスに注目した。例えば，GE はジェットエンジンビジ ネスに拈いて，単にエンジンを販売するのではなく，遠 隔監視システムを通じて不具合が発生する前に警告をし たり，使用年数を伸ばしたり，最適な運航方法を提案し たりするといったサービスを提供している（Kumagai, 2016)。また, 建設機器メーカーの小松製作所も, 従来 の建設機械を販売するだけのモノ売りビジネスモデルか ら，モノとコトの両方を意識したビジネスモデルに転換 しはじめた。例えば，建設機器から得られたデー夕を駆 使して遠隔で効率的な操作方法を指示するなど，建設現 場を総合支援するサービス業への転換を試みている。

このように，空調設備も単に販売するのではなく，そ のあとのメインテナンスや空調のランニングコストの削 減などを含む空気そのものに関連する諸サービスを統合 的に捉えるビジネスモデルの可能性が探索されていた。 さらに，このような新しいビジネスモデル導入には，空 調事業市場を取り巻く環境からも影響を受けることが考 えられる。空調市場の成熟化に伴い, 競合他社の多くが 
機器本体の販売だけでなく, 空調を通して高付加価值の ソリューション事業に移行し始めていたのである。

今日の経済環境では，空調がもし停止してしまうと， 人々の生活に大きな支障が発生することが予想される。 例えば，病院や宿泊施設などでは，暑い夏や寒い冬にお いて，短時間といえども空調の停止は許されない。小林 氏は，このように空調設備を単に所有するのではなく， 何ら心配することなく安定的な空調の提供を求めるニー ズは，ますます高まっていると考えていた。さらに，病 院のような施設では, その特性上, 空調の稼働保証とい う側面だけでなく，空調設備をメインテナンスできる人 手不足，空調設備を新しく導入するための資金不足，ま た部屋ごとや季節ごとに無䭾のない快適な温度設定とい う様々な課題が存在していた。

しかし，売り切り型のビジネスモデルでは，上記のよ うに顧客が抱えている課題に対応することに限界がある。 そこで，製品を販売するという視点から，「空気をサービ スする」という視点に立ち, 空調設備の選定から導入, メインテナンスや部品交換を含む空調に関連するすべて をダイキン工業の専門家が責任をもって提供するという サービス事業への転換を図ったのである。

\section{2. サブスクリプション・サービス「AaaS」}

このように，「快適な空間，空気を提供する」という サービスの発想のもと，「エアアズアサービス株式会社 (AaaS, Air as a Service)」という新しい会社が立ち上がっ た。この会社は，2016 年にダイキンエアテクノ株式会社 と三井物産株式会社の合同出資によって設立された（出 資比率：ダイキンエアテクノ $49 \%$ ，三井物産 51\%，2019 年 12 月 13 日基準)。社名となった $\mathrm{AaaS}^{9)}$ とは, $\mathrm{PaaS}$ (Product as a Service）という視点に基づき，空調事業を 製品の販売ではなく，快適な空気を提供するサービスと して捉えることを意味している。

AaaS は, 高額な空調設備をモノとして購入する必要が なく，毎月定額の利用料を支払うことで空調機を利用で きるサービスである。このようなビジネスモデルは,「サ ブスクリプション方式」のビジネスモデルと呼ばれてい る。サブスクリプション方式のビジネスモデルとは，顧 客が製品やサービスを買い取るのではなく，その利用権
に対価を支払うことであり，利用した期間に応じて料金 を支払う定額制のサービスを意味する。近年，国内でも サブスクリプション方式のビジネスモデルが増えつつ あり，自動車業界では月額定額料金で登録諸費用や毎 年の自動車税, 定期メンテナンス, 任意保険などを含む

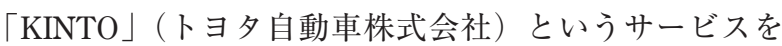
2019 年から開始している。また, 飲食業界では定額制 コーヒー飲み放題の「coffee mafia」(株式会社 favy) とい うサービスが展開されており，他にも美容室のサブスク リプション・サービス「MEZON」（株式会社 Jocy）な ど，様々な分野に扔いてサブスクリプション方式のビジ ネスモデルが展開されている。

サブスクリプション・サービスとしての AaaS の特長 の一つに, カーシェアなどのようなコスト変動型ではな く, 性能保証型であることが挙げられる。つまり, 契約 期間中には月額の料金は固定されて変化せず，導入時の 初期費用やメインテナンスによる追加費用はかからない。 契約期間中はダイキンが稼働状況を分析し, 施設の部屋 ごとに最適な空調の使い方を提案し, 故障の兆候を感知 して事前にメインテナンスをすることでサービス期間中 は稼働が保証される。つまり，AaaS を利用することによ り, 空調設備のライフサイクルコストの「設備導入時に かかるイニシャルコスト」,「修理や補修などのメンテナ ンスコスト」,「空調にかかるエネルギーコスト」のそれ ぞれの一部を削減できるメリットがある。

例えば, AaaS を導入した兵庫県のある病院では, 同 サービスを導入した翌年には電気代を $28.3 \%$ も削減で き, 13 年契約の場合で計算すると, 電気代を含めた顧客 の総費用負担はリース契約と比べて約 $12 \%$ 減る見通しで あるという 10)。

また，AaaS のサブスクリプションのビジネスモデル は，従来から続けてきたリースのビジネスモデルとも異 なるのが特徴的である。同社が展開しているサブスクリ プションとリースの相違点の一つは, 空調設備を選ぶ主 体が異なる点である。リースの場合, 空調を導入する側 の企業が資金の状況や税金などを考慮して自社の状況に 合った設備を選択する。しかし，サブスクリプションの 場合には空調設備の選択の段階からダイキンが行い, 空 調設備の所有権もダイキン側が持つことになる。つまり， 
Marketing Case マーケティングケース — シリーズ 139

設備導入に伴う初期費用を考慮する必要がないため，資 金状況の影響を受けにくく，資金の流れの見通しを立て やすいのである。

\section{AaaS のマーケティング・エクセレンス}

空調事業は，成熟市場と新興国市場における価值提供 と，急速に変化するグローバル市場での最適なものづく りという課題に直面している。このような課題に応えて いくためには，単に優れた製品を開発し続けるだけでな く，ビジネスモデルそのものを見直す必要がある。近年， 製造業のサービス化の重要性が指摘されている中 （Nishioka \& Minami, 2017），ダイキン工業も新たなサー ビス AaaS に乗り出したのである。

これまで紹介してきた AaaS は, ハードウェアとして の製品自体を販売することによらず，製品がその性能に よって生み出された成果を提供する「パフォーマンスベー ス・サービス (Performance based Service)」であり，モ ノの保有よりもその使用価値を重視する PSS（Product Service Systems）という概念で説明できる（Nishioka \& Minami, 2017)。

AaaS という取り組みをPSS という視点から考えると, 成熟化した空調市場において製品を大きく変えることな
く新しい価値を創造し，新たな需要を作り出したところ にマーケティングのエクセレンスがあると考えられる。 つまり, 空調に対する需要は常に存在しているが, 事例 で取り上げた病院や宿泊施設が抱えている課題のように, 既存のモノ売り発想では対応しにくい顧客のニーズも同 時に存在していた（図表 5)。しかし，AaaSでは，新た な空調設備の開発のような製品志向で解決するのではな く, 製品の提供の仕方を変えることで空調稼働を保証す るとともに資金や人手不足の問題にも対応できるという 新たな価值提供といった発想で対応している。

また, AaaS は顧客の潜在的なニーズを捉えることにも 成功している。これまでに空調設備に関するサブスクリ プションのビジネスモデルが存在しなかったため, 空調 に関する顧客からの要望は既存の技術や製品で対応でき る範囲内に留まっていた。顧客側からすると, 空調設備 の所有権を一切持たず，温かい空気・冷たい空気を買う という発想には至らなかった。つまり，顧客が欲しいの は革新的で優れた機能を持つ空調設備でなく，空調によ る「快適な環境」そのものであるという視点の転換によっ て，製品志向の強い企業が陥りやすいマーケティング • マイオピア（Levitt, 1960）から脱却して, 顧客の潜在的 なニーズを汲み上げに成功したと言える。

さらには，製品の所有権を提供側が保持することで得 られる顧客データの収集という側面においてもエクセレ

\section{図表 5 現状の AaaS のターゲット顧客}

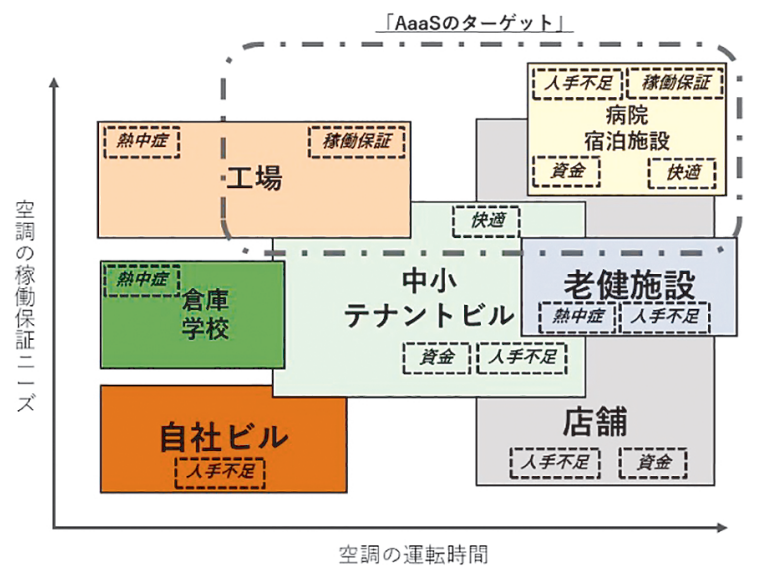

(出典) Daikin Industries, Ltd. (2019b) より作成 
ンスがある。同社は，従来からも空調運転デー夕を遠隔 で収集していたが，それは保守契約を結んだ一部の顧客 に留まっていた11)。しかし，サブスクリプションは保守 契約まで含んだ包括的な契約形態となるため，契約期間 中の顧客データをすべて収集できる。そして，収集した デー夕に基づいて顧客に最適な空調運用を提案でき，電 気代などのエネルギーコストを削減したい顧客のニーズ に応えることができるのである。

上述した $\mathrm{GE}$ 社の事例のように，このような顧客の運 転データの収集は，製品開発時に修理・メインテナンス を想定した製品設計が可能になるということが言われて おり（Nishioka \& Minami, 2017），製品を製造するだけで なくメインテナンスなど製品に必要とされるサービスも， メーカーであるダイキン工業のビジネスモデルの中に取 り組まれることになる。

\section{V. 今後の課題}

今後, AaaS を展開していくうえで, いくつかの課題も 残されている。その一つとして，営業パーソンに対する 評価基準の見直しである。新しいビジネスモデルに乗り 出すためには，そのビジネスモデルに合わせて営業パー ソンの意識を変える必要があり，また彼らの評価基準も 見直さなければならない。

従来は, 顧客に対してより大きな空調システムを売り 达めば，より高く評価をされる傾向にあった。その背景 には，空調が効きすぎることにはそれほど問題はないが, きちんと冷えないあるいは温まらないと問題になるとい う考え方があった ${ }^{12)}$ 。そのため，リスクを回避するとい う意味で，少し大きめの設備を導入することがあった。 もちろん，ダイキン側においても大きな空調システムを 販売すれば，より大きな売り上げへと結びついた。

しかし, AaaSのビジネスモデルでは, どのような設備 が最適かをダイキン側が精査し，最適な空調設備を提案 するため, 結果的には既存の営業よりも小さな設備を提 案するケースも出てくる。つまり，このようなビジネス モデルでは空調設備の売り切り型ではないため, たとえ 従来よりも単価が安い空調機でも，顧客の施設に最適で
あると判断されればそれを導入した方が顧客もエネル ギーコストが抑えられ，ダイキン側も工事費用などが減 る。しかし, 空調機の売上高による従来の営業評価は, こういったケースまで包括しきれていないのが現状であ る。今後, コト売り視点に対する評価の見直しを行わな ければ, 営業部門のモチベーションにネガテイブな影響 を与えかねなく，ビジネスの拡大にとって足かせとなる 危険性がある。

注

1) Daikin Industries, Ltd. (2015)。

2） 2019 年 11 月 12 日に行われた筆者らによるダイキン工業 (株) 専任役員 テクノロー・イノベーションセンター技師 長 小林氏, ダイキンエアテクノ（株）エンジニア リン グ本部 $\mathrm{PaaS}$ 企画部 エアアズサービス推進 $\mathrm{Gr}$ 課長 石川 氏，ダイキン工業（株）コーポレートコミュニケーション 室広報グループ 野田氏へのインタビューによる。

3）前掲注 1) に同様, および Daikin Industries, Ltd. (1996, 2001, 2006, 2011, 2016, 2019a)。

4) Daikin Industries, Ltd. (2019b)。

5）前掲注 2) に同様。

6）前掲注 2) に同様。

7）前掲注 1）に同様。

8）前掲注 1）に同様および前掲注 2）に同様。

9）以下, 本文で取り上げる「AaaS」という名称は, 社名では なくサブスクリプション・サービスである。

10） Nikkei Sangyou Sinbun（2019）（2019 年 11 月参照）。

11）前掲注 2）に同様。

12）前掲注 2）に同様。

\section{References}

Daikin Industries, Ltd. (1996). Dai 92ki yuukashouken houkokusho. (ダイキン工業株式会社 (1996). 『第 92 期有価証券報告 書』) (In Japanese)

Daikin Industries, Ltd. (2001). Dai 97ki yunkashouken houkokusho. (ダイキン工業株式会社 (2001).『第 97 期有価証券報告 書』) (In Japanese)

Daikin Industries, Ltd. (2006). Dai 102ki yuukashouken houkokusho. （ダイキン工業株式会社（2006）。『第 102 期有価証券報告 書』) (In Japanese)

Daikin Industries, Ltd. (2011). Dai 107ki yuukashouken houkokusho. （ダイキン工業株式会社（2011）。『第 107 期有価証券報告 書』) (In Japanese)

Daikin Industries, Ltd. (2015). Daikinkougyou 90nenshi. Hiraku. Osaka: Daikin Industries, Ltd. (ダイキン工業株式会社 (2015)。『ダイキン工業 90 年史拓く』ダイキン工業株式会 社) (In Japanese)

Daikin Industries, Ltd. (2016). Dai 112ki yuukashouken houkokusho. （ダイキン工業株式会社（2016）。第 112 期有価証券報告 書』) (In Japanese)

Daikin Industries, Ltd. (2019a). Dai 115ki yuukashouken houkokusho. 
Marketing Case マーケティングケースー シリーズ 139

(ダイキン工業株式会社（2019a）、『第 115 期有価証券報告 書』) (In Japanese)

Daikin Industries, Ltd. (2019b). 'What's DAIKIN' Kouhou siryou. (ダイキン工業株式会社 (2019b)。『「What's DAIKIN」広報 資料』) (In Japanese)

Kumagai, A. (2016). GE henka no keiei. Tokyo: DIAMOND, Inc. (熊 谷昭彦（2016)。『GE 変化の経営』ダイヤモンド社) (In Japanese)

Levitt, T. (1960). Marketing myopia. Harvard Business Review, 38(4), 45-56.

Nikkei Sangyou Sinbun. (2019). Daikin kuukiwo ure. Nikkei Sangyou Sinbun, August 21, 1.（日経産業新聞（2019）。「夕 イキン空気を売れ」『日経産業新聞』8月 21 日， 1) (In Japanese)

Nishioka, K., \& Minami, C. (2017). 'Seizougyou no sa-bisuka' senryaku. Tokyo: Cyuoukeizaisya.（西岡健一 - 南知恵子 （2017）。『製造業のサービス化」戦略』中央経済社）(In Japanese)

權 純鎬（くおん すんほ）

早稲田大学商学学術院助手。青山学院大学経営学部を卒業 後, 早稲田大学大学院商学研究科修士課程を修了。現在, 同大学大学院商学研究科博士後期課程に在籍。修士 (商学)。 専門は, マーケティング・コミュニケーション, 消費者行動。

\section{恩藏 直人（おんぞうなおと）}

早稲田大学商学学術院教授。早稲田大学商学部卒業後, 同 大学院商学研究科への進学。博士 (商学)。専門は, マーケ ティング戦略。 